\title{
WACE: CULTURAL POLITICS \\ AND THE TRANSLATIO STUDII
}

\author{
José Enrique Ruiz-Domènec \\ Universitat Autònoma de Barcelona \\ JoseEnrique.Ruiz.Domenec@uab.cat
}

The Roman de Brut by Wace was finished in II55, according to the author's confession in line I4865, the penultimate one in his work; almost the same year in which Henry Plantagenet was crowned King of England (II54). It has been rightly said that this work is an Old French version of classic text in Latin, the Historia Regum Britanniae by Geoffrey of Monmouth, in which the wonderful feats of the ancient kings of Britain were narrated.

This data deserves to be closely explained. In the mid-twelfth century, in some territories of Europe, there was a clear option for "translation" from Latin to the vulgar language (French, in the case of Wace), which thus became the first language of courtly society. The nobility and the knights, gathered around a king persuaded of the need to affirm his literary patronage, wanted to listen to short stories that reaffirmed their political status: stories that wanted to reconstruct the past, although they made a strong use of fiction in order to bring this about. But the most important issue at that moment was that these reconstructions of events, these acts of rewriting which started in the work of Wace, took the risk of entering territories that had belonged to the memory of the nobility, one could say exclusively, until that moment.

It is clear that Wace knew very well the profuse legacy of the memoirs of the counts of Anjou, starting with the Fragmentum of Fulk IV le Réchin, as is visible at least in the disconsolate tone in which the role of the ancestors is rendered. Fulk IV (who would afterwards be the great-grandfather of Henry Plantagenet), an excellent narrator, appealed explicitly to a legitimacy of power based on the knowledge of the past, even though evidently, concerning the remembrances conveyed by this interesting character one cannot speak of facts, only of interpretations.

Some years ago, I showed in my book La Memoria de los Feudales (1984) that the elision of historical time that is required in order to maintain a faith in personal conceptions of the past entails a high human and political cost. The shapes that remembrance takes do not stick to the facts, and are neither proportioned 
nor steady in their form. The political implications of this tendency were immediately felt, considering that it led more often to war than to peace, to resentment rather than to reconciliation, and to the resolution of revenge rather than to the hard work of forgiveness.

It is interesting, in more than one sense, to notice the fact that Thomas, canon of Loches, food a way out of this reverie of the nobiliary memory in the Gesta Ambazienzium Dominorum (1555), by presenting universal facts in a way that helped to consolidate the power of a dynasty. Notice the date, II55: this was the same year in which Wace finished the Roman de Brut. This can be considered as a coincidence, but I do not see it as such. I rather see in this the zeitgeist of the period trying to find a new path capable of adapting itself to the demands of a society, which was strongly drawn towards classic culture. Was not Benoît de Sainte-Maure writing the Roman de Troie at the same moment? If remembrance is not efficient anymore, then one must resort to myth.

Wace's point of departure is the traumatic myth of the destruction of Troy, from where Brut escapes, and the exciting possibility of a revival. The rhetoric that accompanies this literary operation is linked (at least in my view) with the values of the Translatio studii and the Translatio imperii. Seen purely from the historical perspective, this recreation of the past can be as nebulous as it is passionate. In fact, the essence of this historical roman can be reduced to this: identification and psychological proximity, rather than historical accuracy or (perhaps even less) political depth. Whether Wace's historical roman is the result of adaptation or of imagination, whether it is a mere invention or whether it recalls a chronicle memory, it has a great significance for modern Romanists; but as most of them have fully understood, it is inconsistent.

The best proof of this argument can be found from line 9005 of the Roman de Brut, happened immediately after "Quant Uther li reis fu finez". The appearance of Arthur, Arthur of Britain, points out that the story does not refer strictly to history anymore, not even to memory itself, but to what we now call the imaginary of a society, its political ideology, its social morality and its juridical principles. This is a real truth of this period of time: a century of agricultural progress had led European society to a paradox. We cannot ignore the act of remembrance that legitimized the dominant dynasties; and yet historical time cannot be understood through the memory of the nobility.

This was the inevitable consequence of the Renaissance of the twelfth century, as described by Charles Haskins, or of the acceleration of the historical process in that period, as identified by Richard Southern. It was not the end of a tradition; instead, it was a search to change it for another one that was endowed with more legitimacy. If the past cannot be forgotten, it can be changed through 
entertainment (in the sense given to the term by Georges Duby), so that everything that lives becomes mere representation. The Plantagenet dynastic state is based on an emotion, one that refers to written works produced within in its own environment. It is for this reason that later Wace composed the Roman de Rou, an eulogium of the first Norman dukes, based on old chroniclers as Dudo of St. Quentin; a chain of texts that Benoit de Sainte Maure would bring to a culmination with his Estoire des Ducs de Normandie, written around II75.

In the end, the Plantagenet circle found in the pedagogy of history a great substitute to the forms of remembrance of their ancestors, which had led directly to a memory of history. But this process entailed a risk. History cannot be written by trying to legitimize memory; this leads to a retrospective where the future is seen as lying in the past, a true présentisme. If the Plantagenet's claimed that what these stories described was what had really happened, a call was being made for other political circles to bring about similar operations. This would be recreated in the Capetian environment, by inventing of the Carolingian world through epic songs of feats. Of course, the key to this process was to find a way that placed literary fiction at its creative core. It is at this point that Chrétien de Troyes appears with his well-read novels, in which we can find a definition of historical time adapted to a society that has come to the conclusion that the recovery of the past is truly a daydream.

\section{BIBLIOGRAPHY}

Arnold, I. (ed.), I940: Le Roman de Brut de Wace, Paris.

Ruiz Doménec, J. E., 1984: La Memoria de los Feudales ( ${ }^{\text {st }}$ ed.), Barcelona. Haskins, C., 1927: The Renaissance of the Twelfth Century ( ${ }^{\mathrm{st}}$ ed), Harvard. Searle, E., 1988: Predatory, Kinship and the Creation of Norman Power, 80-1066, Berkeley.

Southern, R. W., 1953: The Making of the Middle Ages, London and New Haven. 
